\title{
Pengetahuan Konten Pedagogik Guru Matematika Pemula pada Program Linier
}

\author{
Leka Frita Yanuati Haryono $^{1}$, I Nengah Parta ${ }^{1}$, Gatot Muhsetyo ${ }^{1}$ \\ ${ }^{1}$ Pendidikan Matematika-Universitas Negeri Malang
}

\begin{tabular}{l}
\hline \hline INFO ARTIKEL \\
\hline Riwayat Artikel: \\
Diterima: $15-02-2019$ \\
Disetujui: 22-08-2019 \\
\hline
\end{tabular}

\section{Kata kunci:}

pedagogical content knowledge; beginner teacher;

linear program,

pengetahuan konten pedagogik; guru pemula;

program linier

\begin{abstract}
ABSTRAK
Abstract: This study aims to describe the pedagogical content knowledge of beginner mathematics teachers in linear programs. This research is a part of qualitative research with one subject. Data will collected was done by using observation of learning implementation, documentation and interviews. The validated instruments are learning observation sheets and interview guidelines. The results of this study show that pedagogical content knowledge of beginner teachers at level 0 or inadequate teachers. Time teaching experience influence to pedagogical content knowledge mathematics teacher.
\end{abstract}

\begin{abstract}
Abstrak: Penelitian ini bertujuan untuk mendeskripsikan pengetahuan konten pedagogik guru matematika pemula pada program linier dua variabel. Penelitian ini bagian dari penelitian kualitatif dengan subjek satu orang guru pemula. Pengumpulan data melalui pengamatan pelaksanaan pembelajaran, dokumentasi, dan wawancara. Instrumen yang divalidasi adalah lembar pengamatan pembelajaran dan pedoman wawancara. Hasil dari penelitian ini menunjukan bahwa pengetahuan konten pedagogik guru pemula pada level 0 atau guru tidak memadai. Lama mengajar memengaruhi level pengetahuan konten pedagogik guru.
\end{abstract}

\author{
Alamat Korespondensi: \\ Leka Frita Yanuati Haryono \\ Pendidikan Matematika \\ Universitas Negeri Malang \\ Jalan Semarang 5 Malang \\ E-mail: lekafrita4186@gmail.com
}

Keterampilan seorang guru dalam mengajar merupakan faktor penting penentu kualitas pembelajaran, dan dapat memengaruhi peningkatan belajar dan perkembangan motivasi belajar peserta didik (Baumert et al., 2010). Menurut (Aunurrahman, 2010) guru harus dapat mengambil keputusan yang tepat untuk siswanya karena guru merupakan salah satu faktor eksternal belajar yang memengaruhi siswa. Bukan hanya materi yang kuat yang diperlukan sebagai seorang guru, strategi seorang guru untuk mengajarkan materi tersebut juga merupakan hal yang penting. (Purwianingsih, Rustaman, \& Redjeki, 2010) memperkenalkan hal tersebut dengan nama pedagogical content knowledge atau pengetahuan konten pedagogi. (Purwianingsih et al., 2010) menyatakan bahwa pengetahuan konten pedagogik merupakan perpaduan antara isi materi dan pedagogik, dalam hal ini ditekankan pada aspek isi materi yang berhubungan erat dengan bagaimana cara mengajarkan isi materi tertentu tersebut agar mudah diajarkan (teachability) dan mudah dipahami siswa (accesable).

Kompetensi guru profesional oleh Shulman digambarkan sebagai tiga pilar pengetahuan yaitu pengetahun materi (content knowledge), pengetahuan pedagogi (pedagogical knowledge) dan bidang spesifik interseksi antara CK dan PK yang dinamakan Pedagogical Content Knowledge. Sebagai pencetus pengetahuan konten pedagogik, Shulman menjabarkan dalam tujuh komponen, yaitu (1) pengetahuan tentang materi, (2) pengetahuan tentang tujuan pembelajaran, (3) pengetahuan tentang peserta didik, (4) pengetahuan tentang organisasi kurikulum, (5) pengetahuan tentang mengajar, (6) pengetahuan tentang evaluasi, dan (7) pengetahuan tentang sumber daya.

(Purwianingsih et al., 2010) menyarankan pengetahuan konten pedagogik membentuk domain pengetahuan yang unik dan berbeda tentang kognisi guru. Pengetahuan konten pedagogik menekankan pada cara guru menghubungkan pengetahuan materi pelajaran dengan pengetahuan pedagogi, juga bagaimana pengetahuan materi pelajaran adalah bagian dari proses pemikiran pedagogis. Pengetahuan konten pedagogik menurut Kwong, et al. (2007) dipandang sebagai daerah asal pengetahuan mengajar khas yang membedakan guru ahli dalam pembelajaran dengan ahli pelajaran. (Darling-Hammond, 2006) menunjukkan bahwa konsensus yang muncul adalah bahwa pengetahuan guru tentang pedagogi adalah penting untuk dapat menyajikan topik dalam berbagai mata pelajaran dengan cara yang yang dapat dipahami. Sementara itu, (Holt-Reynolds, 1992; Kagan, 1992) menegaskan bahwa penelitian telah menunjukkan bahwa guru pemula sering berjuang untuk menghadirkan konsep yang dimengerti oleh siswa mereka tapi mereka hanya memiliki pengetahuan konten pedagogik sedikit atau tidak milikinya sama sekali. Dari penjelasan di atas, dapat dilihat bahwa pengetahuan konten pedagogi merupakan dasar pengetahuan penting yang harus 
dimiliki guru untuk mengajarkan materi matematika secara efektif. (Koehler \& Mishra, 2008) melihat pengetahuan konten pedagogik sebagai "pengetahuan dasar yang berkaitan dengan representasi dan perumusan konsep, teknik pedagogis, dan pengetahuan tentang apa yang membuat sebuah konsep sulit atau mudah untuk dipelajari, dan pengetahuan awal siswa", pandangan yang sama dengan (Purwianingsih et al., 2010) tentang pengetahuan konten pedagogik.

(Karahasan, 2010) mengklasifikasi pedagogical content knowledge atau pengetahuan konten pedagogik menjadi tiga level, yaitu level 0, level 1, dan level 2. Level 1 adalah guru yang tidak memadai, level 1 guru yang baik dan level 2 adalah guru yang kuat. Level 0 atau guru tidak memadai ciri-cirinya adalah (1) satu-satunya penyedia informasi; (2) menggunakan representasi tunggal, dan juga kesulitan menghubungkan dengan topik yang berbeda atau sub unit; (3) mengalami kesulitan dalam menyusun rencana pelaksanaan pembelajaran yang sesuai tujuan pembelajaran; (4) tidak dapat mengidentifikasi kesalahan siswa juga kesulitan dalam mengendalikan kelas; (5) jika siswa mengalami kesulitan langsung memberikan jawaban dan penjelasan; (6) sumber belajar yang hanya berasal dari buku teks. Level 1 yaitu guru baik ciri-cirinya adalah (1) tidak hanya memberikan pengetahuan prosedural saja, namun juga membantu siswa dalam mengembangkan pengetahuan; (2) menggunakan multiple representasi untuk membantu siswa dalam menyelesaikan kesulitan; (3) mengalami kesulitan dalam menyusun topik atau masalah dalam rencana pelaksanaan pembelajaran yang sesuai tujuan pembelajaran; (4) dapat mengidentifikasi kesalahan siswa namun contoh yang diberikan pada pembelajaran hanya fokus pada kesalahan yang ditemukan; (5) memberikan contoh soal yang setara agar dapat membatu siswa yang mengalami kesulitan; (6) sumber belajar tidak hanya dari buku teks, namun masih kesulitan dalam aplikasi.

Level 2 guru kuat ciri-cirinya adalah (1) menjadi fasilitator dalam membangun pengetahuan siswa melalui diskusi dan penyelidikan; (2) menggunakan representasi yang berbeda, serta dapat menghubungkan dengan topik yang berbeda dan aplikasinya. (3) dapat menyusun secara urut topik dan masalah dalam rencana pembelajaran yang sesuai dengan tujuan pembelajaran; (4) dapat mengidentifikasi kesalahan siswa dan menjadi falitator dalam setiap kesalahan peserta didik; (5) memfasilitasi siswa yang mengalami kesulitan dengan memberikan pertanyaan-pertanyaan; (6) sumber belajar dari siswa, sekolah dan lingkungan juga dapat mengaplikasikannya.

Berdasarkan penjelasan di atas, pengetahuan konten pedagogik merupakan pengetahuan yang terdapat pada guru, tidak sekedar melingkupi hal-hal yang berkaitan dengan pengetahuan pedagogis semata ataupun hal-hal yang berkaitan dengan pengetahuan materi saja. Dalam memutuskan aspek-aspek dalam mengajar, guru menggunakan pengetahuan pedagogis sekaligus pengetahuan isi materi. Selain itu, guru harus memiliki pengetahuan konten pedagogik untuk mengajar mata pelajaran mereka secara efektif. Materi program linier pada penelitian ini adalah progam linier pada kelas XI sesuai dengan kurikulum 2013 edisi revisi. Kompetensi dasar dalam kurikulum 2013 ada dua, yaitu kompetensi dasar pengetahuan dan keterampilan. Adapun komperensi dasar pengetahuan pada proram linier adalah menjelaskan program linier dua variabel dan metode penyelesaiannya dengan menggunakan masalah kontekstual, dan untuk keterampilan adalah menyelesaikan masalah kontekstual yang berkaitan dengan program linier dua variabel. Masalah kontekstual yang dimaksud adalah soal cerita tentang menentukan nilai optimum program linier.

Sudah banyak peneliti yang meneliti tentang kemampuan konten pedagogik guru matematika yaitu (Agustiani, 2015) pada dua orang calon guru menghasilkan kesimpulan bahwa level pengetahuan konten pedagogik kedua mahasiswa calon guru yang berada pada level 1. Hal ini mengindikasikan bahwa level pengetahuan konten pedagogik mahasiswa calon guru masih harus terus dikembangkan melalui kegiatan perkuliahan dan praktik pengalaman lapangan. (Mastuti, 2017) melakukan studi kasus pada satu orang guru tentang pengetahuan konten pedagogik guru dalam pemberian tugas dalam kelas. Kesimpulan yang didapat dalam penelitian itu dalam yang menjadi pertimbangan utama guru dalam pengambilan keputusan penugasan di kelas adalah kemampuan siswa. Hal tersebut menjadi salah satu dasar peneliti ingin mendeskripsikan tentang pengetahuan konten pedagogik guru matematika pemula dalam pembelajaran program linier dua variabel. Penelitian ini bertujuan untuk mengetahui pengetahuan konten pedagogik guru matematika pemula dalam pembelajaran program linier dua variabel. Hal tersebut dikarenakan bahwa guru merupakan salah satu faktor penting dalam pembelajaran, maka hasil penelitian ini diharapkan dapat memberikan gambaran kualitas guru ketika menyampaikan konsep di kelas.

\section{METODE}

Penelitian ini merupakan bagian dari penelitian kualitatif. Subjek pada penelitian ini satu orang guru matematika pemula yang mengajar selama <10 tahun. Penelitian ini dilaksanakan di SMA Katolik Surabaya pada semester ganjil tahun 2018/2019 pada satu (1) orang guru yang mengampu pembelajaran matematika. Guru tersebut adalah guru pemula dengan lama mengajar satu tahun empat bulan. Penelitian ini dilakukan untuk melihat pengetahuan konten pedagogik guru matematika pemula pada program linier. Penelitian ini menggunakan pendekatan kualitatif, yaitu dilakukan pada kondisi yang alamiah (langsung ke sumber data) dimana peneliti sebagai instrumen kunci. Dalam mendeskripsikan pembelajaran ini dikaitkan dengan pelevelan (Karahasan, 2010). 
Penelitian diawali dengan melakukan penelusuran pengalaman mengajar guru, dipantau saat persiapan pembelajaran kemudian dilakukan pengamatan pembelajaran. Data hasil penelitian dianalisis dengan teknik deskriptif kualitatif. Teknik pengumpulan data dilakukan dimulai dari validasi instrumen, pengamatan pelaksanaan pembelajaran, dan wawancara. Dokumen yang divalidasi adalah lembar pengamatan pembelajaran, dan pedoman wawancara. Pengamatan pelaksanaan pembelajaran adalah pengamatan langsung pada saat guru melakukan pembelajaran program linier di kelas. Guru mengetahui bahwa sedang dilakukan observasi untuk penelitian. Wawancara dilakukan dengan guru untuk menggali alasan dan konsep pemikiran guru melakukan pembelajaran seperti yang direncanakan dan dilaksanakan. Data yang disajikan merupakan rekap dari data guru tersebut.

\section{HASIL}

S1 merupakan guru pemula, dengan pengetahuan konten pedagogik level 0. Tahap perencanaan S1 tidak menyusun sendiri rencana pelaksanaan pembelajaran, melainkan menggunakan hasil dari musyawarah guru mata pelajaran (MGMP). Pada pelaksanaan pembelajaran representasi yang disajikan S1 pada setiap pertemuan hanya dengan satu cara, yaitu cara yang sesuai dengan buku paket. S1 juga tidak menghubungkan program linier dengan topik ataupun sub unit lain. S1 tidak dapat mengidentifikasi kesalahan maupun kesulitan peserta didik, saat siswa mengalami kesulitan maka S1 langsung membantu siswa untuk membetulkan kesalahan tersebut. Pusat informasi pada saat pembelajaran hanyalah S1, juga tidak dapat mengendalikan suasana kelas. Sumber belajar S1 berasal hanya dari buku paket yang disediakan oleh sekolah. Materi yang disajikan oleh S1 pada pertemuan pertama adalah tentang menentukan daerah selesaian pertidaksamaan linier, pertemuan kedua membahas tentang fungsi objektif dan soal cerita, dan pertemuan ketiga membahas tentang penyelesaian soal kontekstual pada program linier dua variabel.

\section{Pengetahuan Materi}

Materi yang disampaikan S1 pada pertemuan pertama adalah menentukan daerah penyelesaian dari sistem pertidaksamaan linier dua variabel. Gambar 1 menunjukkan langkah pertama dalam menentukan daerah selesaian pertidaksamaan linier yaitu menentukan titik potong dengan sumbu $\mathrm{x}(\mathrm{y}=0)$ dan sumbu y $(\mathrm{x}=0)$ seperti pada gambar 1a dan 1b. Pada langkah pertama ini S1 tidak membuat permisalan pertidaksamaan menjadi persamaan untuk menentukan titik potong seperti pada Gambar 1c. S1 menentukan daerah selesaian pertidaksamaan dengan cara menguji titik $(0,0)$ seperti pada gambar 1 d. Gambar $1 \mathrm{e}$ menunjukan bahwa jika hasil subtitusi titik uji bernilai benar maka daerah selesaian (arsiran) mendekati titik uji dan jika bernilai salah maka daerah selesaian (arsiran) menjauhi titik uji seperti pada gambar 1 dan 2.

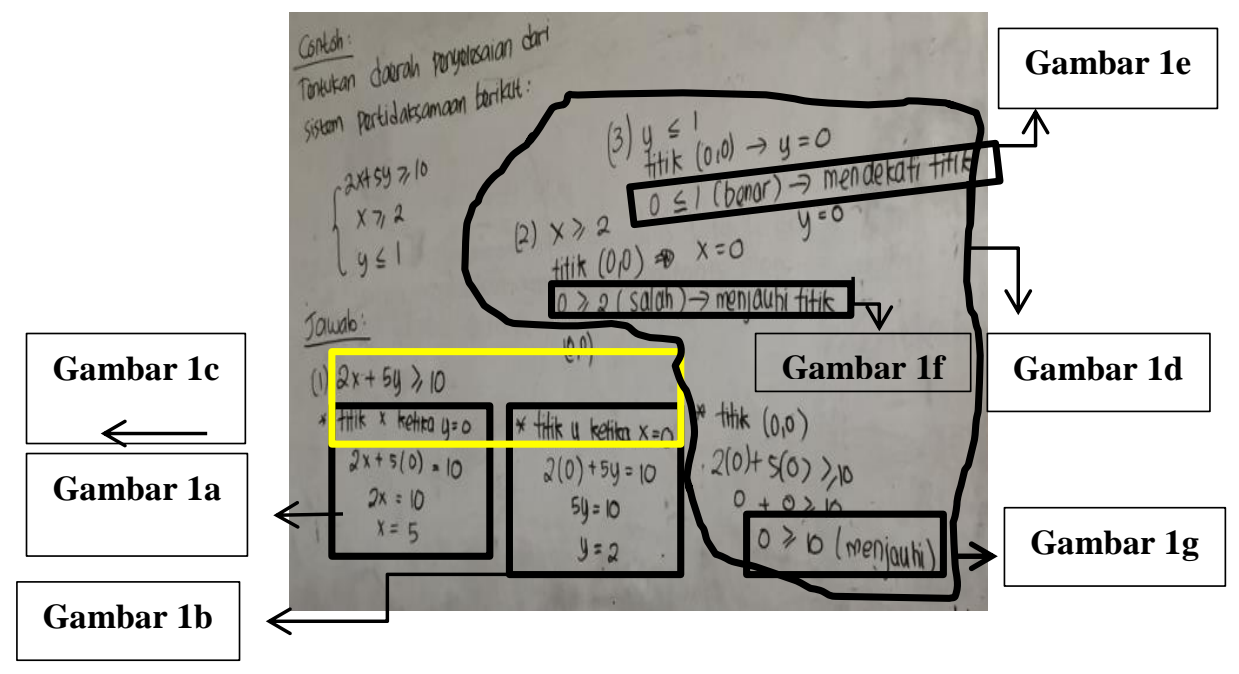

Gambar 1. Reprsentasi S1 pada Pertemuan Pertama

Gambar 2 menunjukan langkah berikutnya yaitu menentukan daerah selesaian pertidaksamaan dengan menggambar pada bidang cartesius. Gambar $2 \mathrm{a}$ menunjukan titik potong garis $2 \mathrm{x}+5 \mathrm{y}=10$ dengan sumbu y dan gambar $2 \mathrm{~b}$ menunjukan titik potong garis $2 \mathrm{x}+5 \mathrm{y}=10$ dengan sumbu $\mathrm{x}$. Gambar $2 \mathrm{c}$ menunjukan garis $\mathrm{x}=2$ dan gambar $2 \mathrm{~d}$ menunjukan garis $\mathrm{y}=1$. Gambar $2 \mathrm{e}$ adalah daerah himpunan penyelesaian system pertidaksamaan linier : $2 x+5 y \geq 10, x \geq 2$ dan $y \leq 1$. 


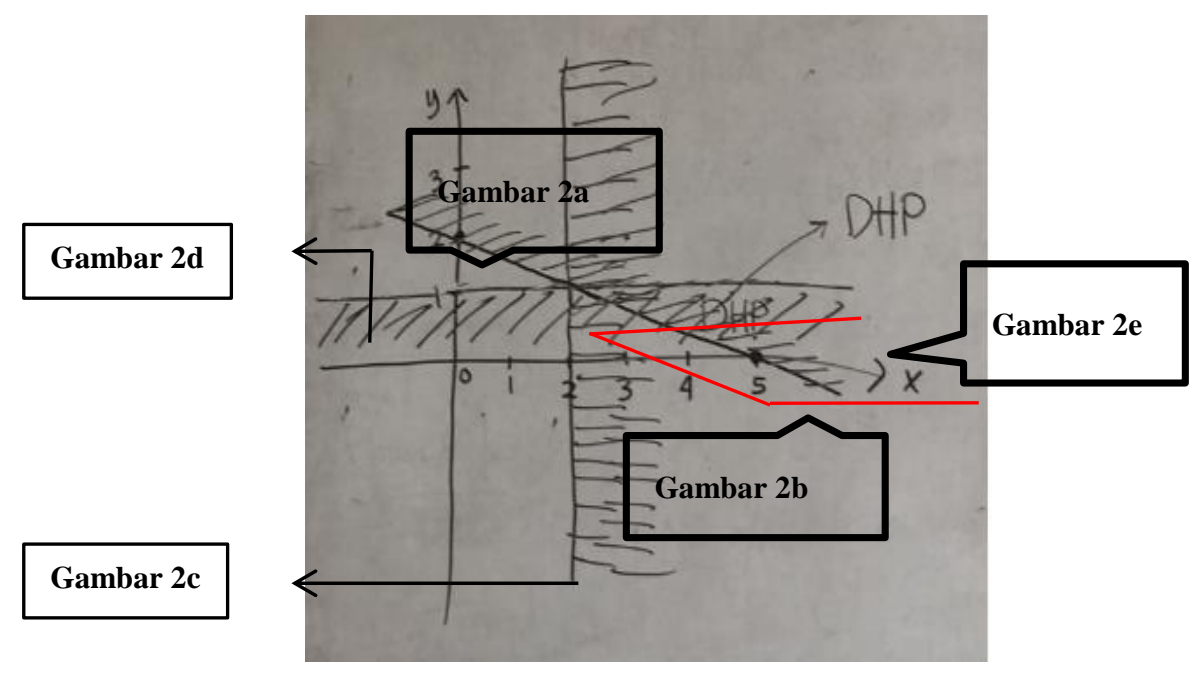

\section{Gambar 2. Representasi S1 Langkah Kedua Pertemuan Pertama}

Representasi yang disajikan di atas menimbulkan kebinggunan pada peserta didik. Peserta didik kesulitan menentukan daerah himpunan penyelesaian hal tersebut dikarenakan daerah yang diarsir bertumpuk-tumpuk. S1 mengubah arah arsiran,yang menjadi daerah selesaian pertidaksamaan linier adalah daerah yang bersih seperti pada gambar 3 .

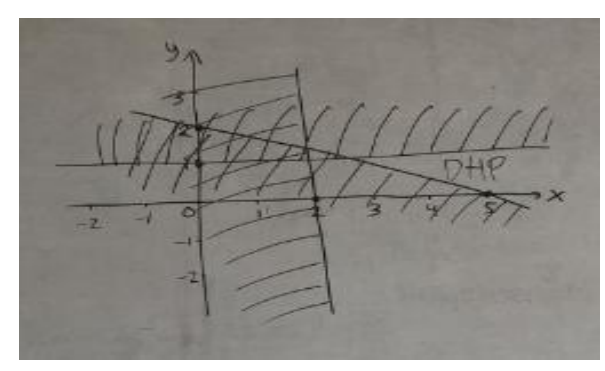

\section{Gambar 3. Perbaikan Daerah Himpunan Penyelesaian oleh S1}

Wawancara dilakukan mengetahui alasan S1 merepresentasikan selesaian pertidaksamaan linier dua variabel seperti padapertemuan pertama, demikian petikan wawancaranya:

P : : Mengapa ibu mengubah penjelasan yang pertama?.

S1 : Ternyata anak-anak binggung bu, tidak dapat melihat dimana letak DHP nya, karena tumpuk-tumpuk arsirannya. Makanya saya ganti saja bu biar DHPnya yang bersih.

P : Menurut Ibu apakah cara lain?

S1 : Eeem, mungkin ada bu tapi saya hanya mengikuti buku paket saja.

Pertemuan kedua S1 merencanakan membahas tentang fungsi objektif dan soal cerita, namun pada pelaksanaannya S1 hanya menjelaskan tentang fungsi objektif. Representasi yang disajikan oleh S1 pada pertemuan kedua seperti pada gambar 4 S1 memberikan sebuah contoh soal dari buku paket yang dimiliki siswa kemudian menjelaskan setiap langkah penyelesaian. Peserta didik diminta untuk meneruskan atau mencontoh apa yang sudah dilakukan oleh $\mathrm{S} 1$.

Gambar 4a dan 4b menunjukan pengerjaan guru tentang selesaian pertidaksamaan linier dua variabel. Alasan S1 mengerjakan bagian tersebut adalah untuk menyingkat waktu. Gambar 4c menunjukan contoh S1 dalam menentukan titik potong antara dua garis. Setelah diberikan contoh S1 meminta peserta didik untuk mengerjakan titik yang lain, gambar 4d dan 4e menunjukan pengerjaan peserta didik untuk menentukan titik potong antara dua garis. Gambar $4 \mathrm{~g}$ menunjukan contoh $\mathrm{S} 1$ menentukan nilai maksimum ataupun minimum dengan mensubtitusikan titik pojok daerah himpunan penyelesaian. Gambar $4.8 \mathrm{f}$ menunjukkan pengerjaan peserta didik dalam menentukan nilai optimum. Kesimpulan diberikan oleh S1 seperti pada gambar $4 \mathrm{~h}$. 


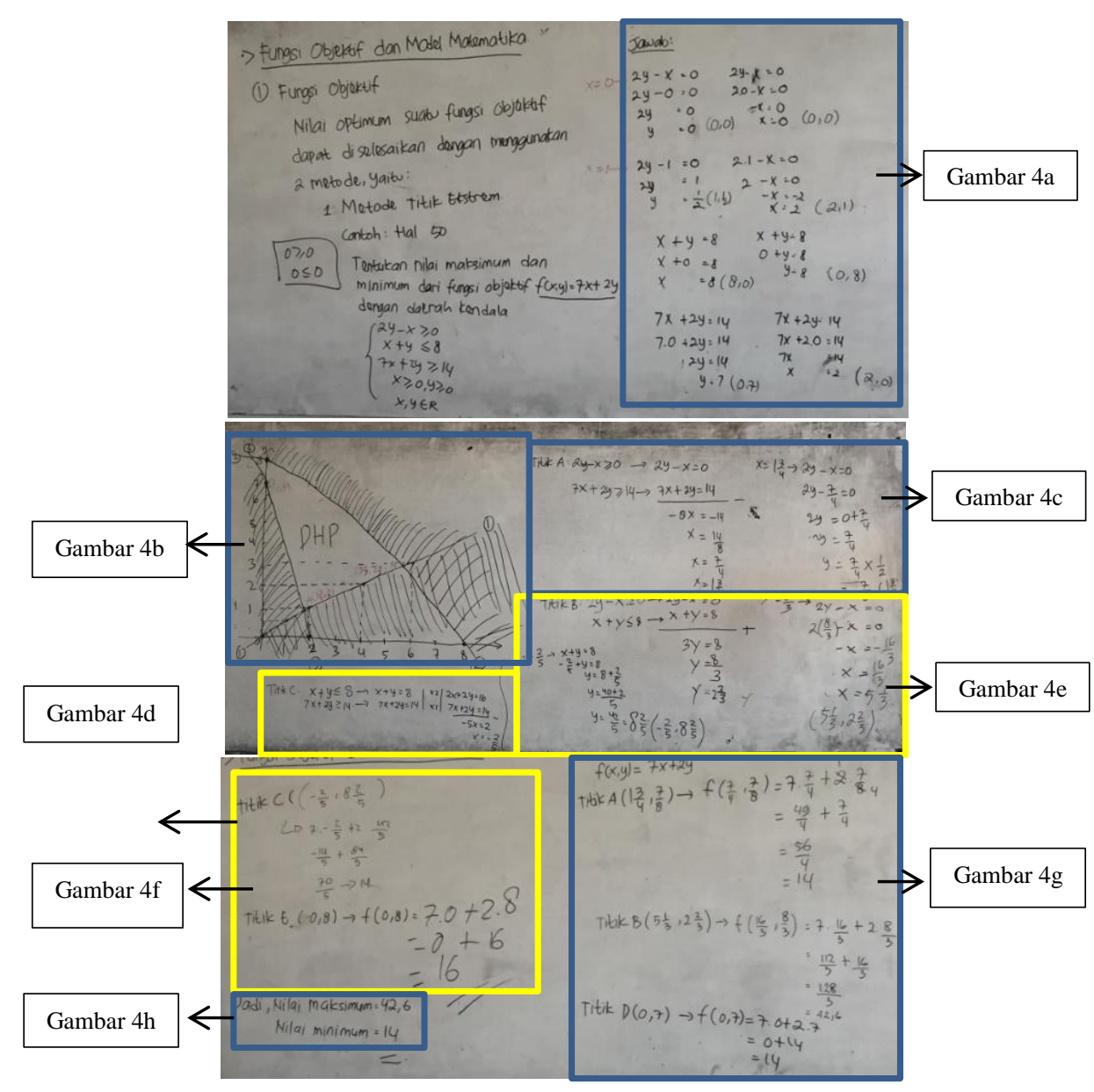

Gambar 4. Representasi S1 pada pertemuan kedua metode uji titik pojok

Gambar 5 menunjukkan sajian S1 dalam menentukan nilai optimum dengan metode yang kedua yaitu menggunakan garis selidik. Peseta didik diminta membuka buku paket kemudian S1 membacakan langkah perlangkah menentukan nilai optimum dengan menggunakan garis selidik. Saat dikonfirmasi S1 merasa bahwa peserta didik dapat mengikuti penjelasannya dengan bantuan buku paket.

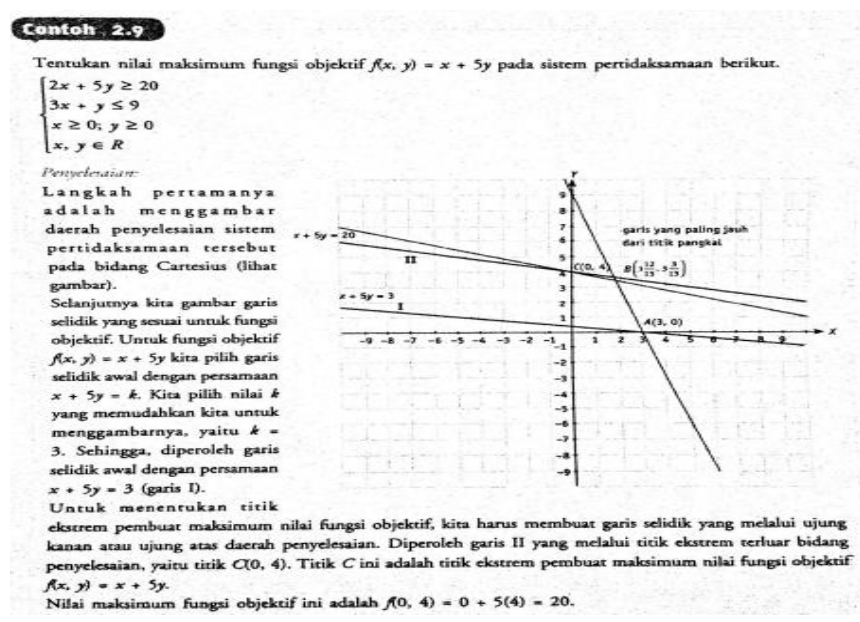

Gambar 5. Contoh Metode Garis Selidik 
Selanjutnya peneliti melakukan wawancara dengan S1 terkait dengan hasil pengamatan di kelas. Berikut adalah hasil wawancaranya:

$\mathrm{P} \quad$ : Mengapa ibu menjelaskan penentuan nilai optimum seperti pada pembelajaran hari ini?.

S1 : Di buku paket ya memang seperti itu bu, jadi saya hanya mengikuti buku paket saja bu.

P : Mengapa ibu saat menjelaskan penggunaan garis selidik hanya membacakan saja? Tidak menulis di papan seperti sebelumnya?.

S1 : Eeem, waktunya itu terlalu lama bu, menggambarnya kan harus satu-satu, anak-anak pasti bisalah bu mengikuti dari buku paket. Kan tadi saya juga sudah menjelaskan langkah perlangkah.

Berdasarkan gambar dan kutipan wawancara, representasi S1 pada pertemuan kedua ada dua bentuk yaitu menggunakan uji titik pojok dan juga metode garis selidik. Hal tersebut dikarenakan S1 mengikuti langkah-langkah pada buku paket yang digunakan di sekolah.

Pertemuan ketiga, S1 membahas tentang model matematika dari soal kontekstual dan juga penyelesaian program linier, contoh yang diberikan adalah dari buku paket seperti pada gambar 7. Representasi yang disajikan oleh S1 seperti pada gambar 7 . Berdasarkan gambar 7a S1 memberikan representasi bentuk tabel, hal tersebut juga sesuai yang ada pada buku paket. S1 juga menyarankan siswa untuk membentuk model matematika dalam bentuk paling sederhana seperti pada gambar $7 \mathrm{a}$ dan $7 \mathrm{~b}$, untuk proses selanjutnya peserta didik diminta untuk memperhatikan buku paket masing-masing.

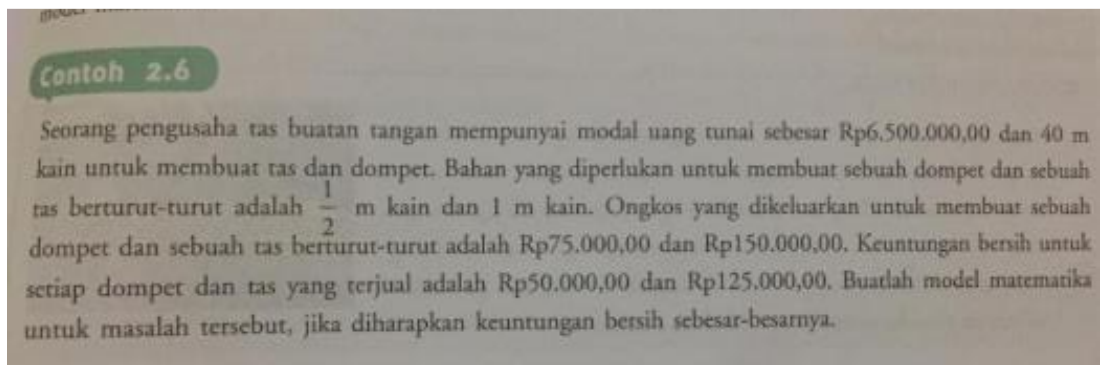

Gambar 6. Contoh Soal Kontekstual oleh S1

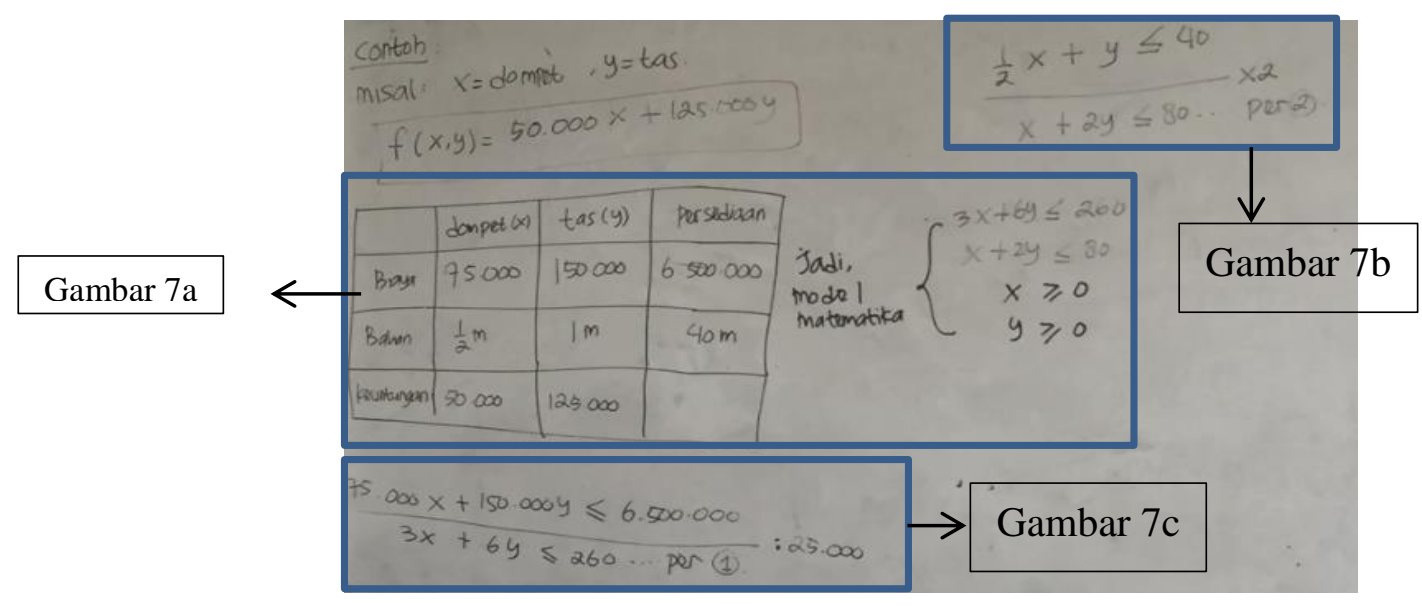

Gambar 7. Representasi S1 pada Pertemuan Ketiga tentang Model Matematika dari Masalah Kontekstual

Saat membahas penyelesaian masalah kontekstual pada program linier S1 tidak mencatat di papan, hanya membaca dari buku paket dan siswa diminta untuk memperhatikan. S1 meminta peserta didik untuk memilih salah satu cara menentukan nilai optimum yaitu memakai cara uji titik pojok ataupun garis selidik. Saat pembelajaran berlangsung S1 hanya mencontohkan seperti pada buku paket yaitu menggunakan uji titik pojok seperti pada gambar 8 . 


\section{contoh 2 , 10}

Suatu pabrik keripäk mempunyai fasilitas produksi untuk menghasilkan dua produk yang berbeda. Masingmasing produk memerlukan tiga bagian operasi yang berbeda, yaitu pemotongan, penfororengan, dan penirisan. Produk A memerlukan wakru 18, 80, dan 70 decik. Sedangkan, produk B memerlukan wakru 35, 35, dan 40 detik. Sumber daya yang tensedia untuk ketiga bagjan operasi ini masing-masing adalah paling sedikit $10 \mathrm{jam}$ untuk waktu pemotongan, 15 jam untuk waktu penggorengan, dan 14 jam untuk waktu penirisan. Jika untuk menghasilkan 1 unit produk A mengeluarkan biaya sebesar Rp5,000,00 dan 1 unit produk B sebesar R $7.500,00$, berapakah jumlah masing-masing produk yang harus dihasilkan agar dapat meminimumkan biaya operasi pabrik tersebut?

Pexpricisaian:

Permasalahan di acas dapat disajikan dalam tabel berikut.

\begin{tabular}{|l|c|c|c|}
\hline & Produk A & Produk B & Surnber Daya \\
\hline Pemotongan & 18 & 35 & 10 jam (36.000 detik) \\
\hline Penggorengan & 80 & 35 & 15 jam (54.000 detik) \\
\hline Penirisan & 70 & 40 & 14 jam (50.400 detik) \\
\hline Biaya & 5.000 & 7.500 & \\
\hline
\end{tabular}
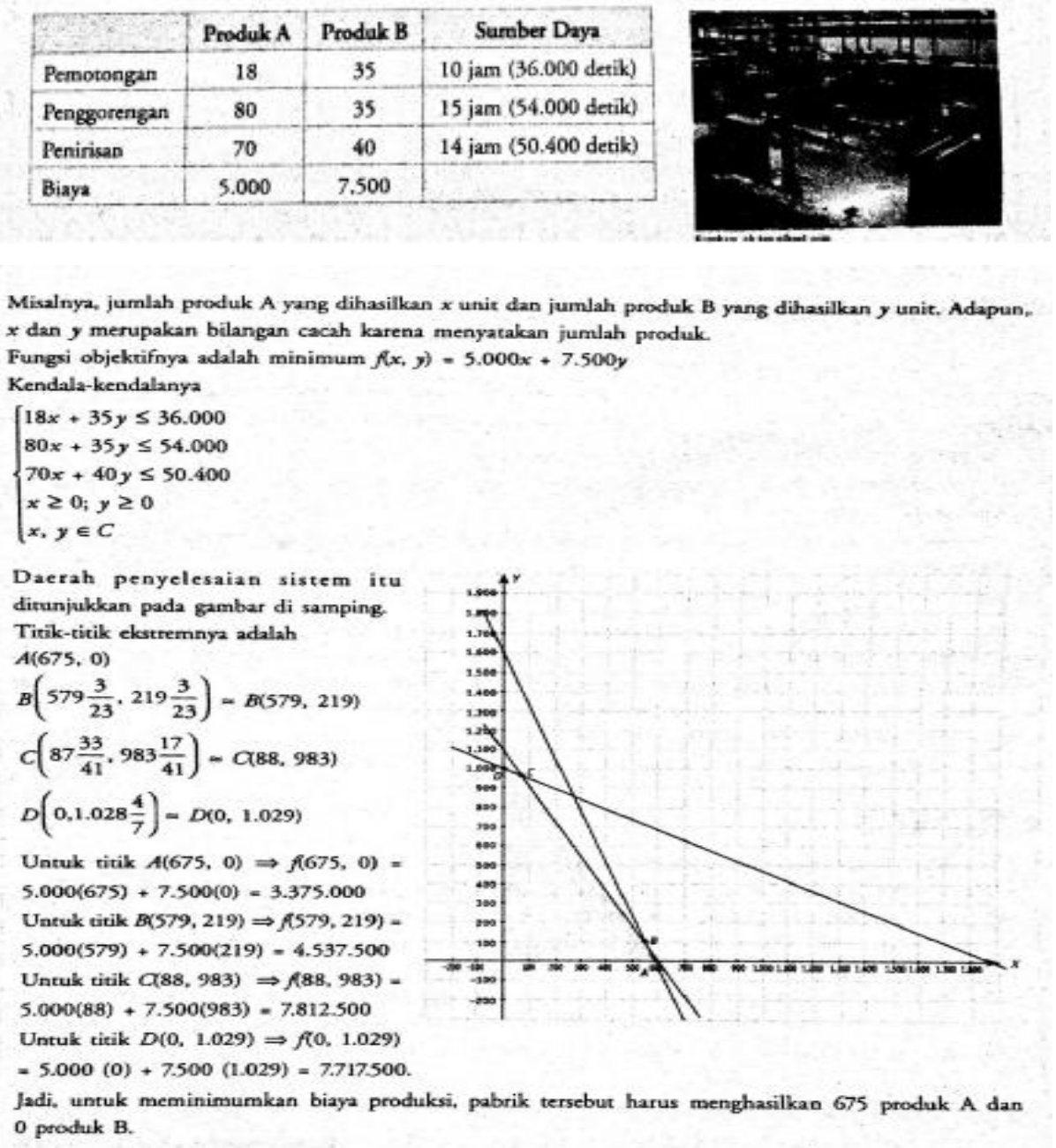

\section{Gambar 8. Contoh Soal Menentukan Selesaian Soal Kontekstual Pada Program Linier}

Berdasarkan gambar 8 dan juga pengamatan pada ketiga pertemuan, representasi yang disajikan S1 bergantung dengan buku paket yang disediakan oleh sekolah. S1 berpendapat bahwa pembelajaran harus sesuai dengan buku paket, juga lebih mudah dalam menjelaskan karena setiap anak memiliki buku paket. Representasi yang disajikan oleh S1 hanya satu cara alasan S1 agar peserta didik tidak mengalami kebinggungan, jika banyak cara maka peserta didik akan binggung memilih cara yang mana yang dipakai. Seharusnya S1 dapat memberikan beberapa representasi, contonya seperti pada pertemuan pertama saat menentukan titik potong garis dengan sumbu $\mathrm{x}$ dan $\mathrm{y}, \mathrm{S} 1$ dapat menyajikan dalam bentuk tabel. Pada pertemuan ketiga saat menyusun model matematika seharusnya $\mathrm{S} 1$ juga dapat memberikan alternatif selain menggunakan tabel. 
Berdasarkan pengamatan pada ketiga pertemuan, saat awal pembelajaran S1 hanya mengecek ketidakhadiran siswa dan menanyakan materi pembelajaran sebelumnya, kemudian langsung menjelaskan pada materi. S1 tidak menghubungkan program linier dengan topik ataupun sub unit yang lain.

\section{Pengetahuan tentang tujuan pembelajaran}

Rencana pelaksanaan yang dimiliki oleh S1 sudah sesuai dengan tujuan pembelajaran, namun rencana pembelajaran tersebut tidaklah dibuat sendiri namun diperoleh dari musyawarah guru mata pelajaran. Pada saat pengamatan peneliti melihat ketidaksesuaian rencana pelaksanaan pembelajaran dengan pembelajaran yang berlangsung. Peneliti melakukan wawancara terkait ketidaksesuaian tersebut, demikian petikan wawancaranya:

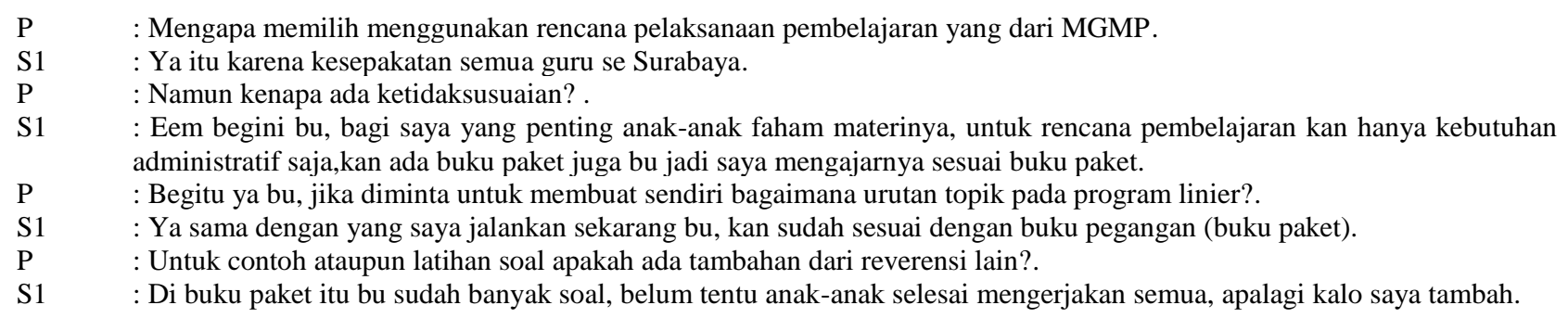

Berdasarkan petikan wawancara di atas menunjukan bahwa S1menggunakan rencana pelaksanaan pembelajaran dari MGMP karena S1 mengalami kesulitan dalam menyusun secara urut topik dan masalah. S1 berpendapat bahwa urutan topik harus sesuai dengan buku paket.

\section{Pengetahuan tentang Peserta Didik}

Berdasarkan pengamatan S1 kurang memahami beberapa kesalahan ataupun kesulitan yang biasa dialami oleh peserta didik. Hal tersebut dapat terlihat salah satunya dari rencana pembelajaran tidak dibuat sendiri oleh S1, jadi tidak sesuai kebutuhan siswa. S1 mengklaim bahwa anak-anak akan lebih mudah mengerti jika dijelaskan padahal belum pernah mencoba dengan metode lain selain pembelajaran langsung dengan metode ceramah. Selanjutnya, peneliti melakukan wawancara untuk lebih menggali informasi, demikian petikan wawancaranya:

$\mathrm{P} \quad$ : Kesulitan apa yang baisanya dialami peserta didik pada program linier?

S1 : Kalau matematika sih pasti semua sulit bu bagi anak-anak, dengar kata matematika saja sudah tidak suka.

P : Jika khusus program linier?.

S1 : Ya sama bu semua bagian susah.

Berdasarkan kutipan wawancara di atas didapatkan bahwa S1 memang kurang memahami kesulitan ataupun kesalahan yang biasa dilakukan siswa pada program linier dua variabel.

\section{Pengetahuan tentang Mengajar}

Pertemuan pertama sampai ketiga satu-satunya penyedia informasi dikelas adalah S1. Peserta didik tidak pernah diminta untuk mencari di internet atapun diajak berdiskusi, hanya sesekali siswa diminta untuk melanjutkan pekerjaan guru seperti pada Gambar 4.8. S1 selalu memberikan contoh terlebih dahulu kemudian meminta peserta didik untuk melanjutkan. Saat dikonfirmasi mengapa memilih pembelajaran langsung S1 mengganggap bahwa paling siswa lebih mudah memahami jika dengan pembelajaran langsung. Demikian petikan wawancaranya.

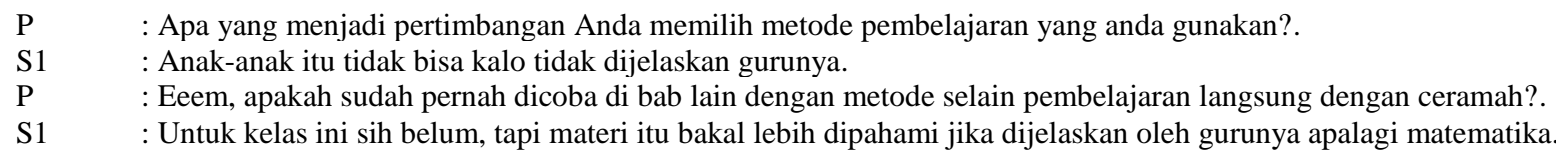

\section{Pengetahuan tentang Evaluasi}

Saat siswa mengalami kesulitan atau kesalahan S1 selalu langsung membetulkan kesalahan tersebut seperti pada gambar 9. Hal tersebut terjadi pada ketiga pertemuan saat S1 meminta siswa untuk mengerjakan di papan tulis ataupun saat pengerjaan latihan soal. Pemberian jawaban kepada siswa yang mengalami kesulitan semakin terlihat pada pertemuan ketiga saat pengerjaan latihan soal, beberapa siswa menanyakan soal-soal yang kurang dimengerti dan S1 langsung memberikan solusi. 


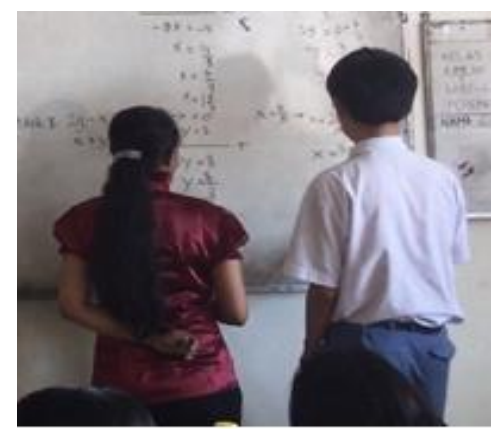

\section{Gambar 9. S1 Memberikan Batuan Lansung Pada Siswa Yang Mengalami Kesulitan}

\section{Pengetahuan tentang Sumber Daya}

Sumber belajar yang digunakan guru yaitu buku paket. Saat dikonfirm;asi S1 menyatakan bahwa beliau maksimalkan buku yang dipunyai peserta didik agar mudah mengontrolnya, demikian petikan wawancaranya

$\mathrm{P} \quad$ : Media pembelajara apa yang Anda gunakan.

S1 : Buku paket, dan alat-alat lainya (pengaris, papan, spidol).

$\mathrm{P} \quad$ : Apakah tidak ada yang lain?.

S1 : : Apa lagi ya?.

$\mathrm{P} \quad$ : Contoh-contoh yang anda berikan apakah semua dari buku paket?.

S1 : Iya bu, saya maksimalkan buku paket.

$\mathrm{P} \quad$ : Mengapa?

S1 : Kan lebih enak kalo anak sudah punya bahanya, saya tinggal menjelaskan.

P : Untuk sumber belajar lain?

S1 : Ya sebenarnya banyak bu bisa dari internet atau juga sumber-sumber lain, tapi saya memaksimalkan buku yang ada.

Berdasarkan kutipan wawancara diatas sebenarnya S1 mengerti bahwa banyak sumber belajar yang dapat dimanfaatkan, namun S1 lebih memilih memaksimalkan buku paket yang ada.

\section{PEMBAHASAN}

Subjek pertama adalah guru pemula, dengan pengalaman mengajar satu tahun, enam bulan. Pengamatan ini dilakukan selama tiga kali pertemuan sesuai dengan rencana pelaksanaan pembelajaran yang dimiliki oleh subjek. Ciri-ciri subjek ketika sedang mengajar pada ketiga peremuan sebagai berikut: (1) representasi yang disajikan subjek pada setiap pertemuan hanya dengan satu cara, juga tidak menghubungkan program linier dengan topik ataupun sub unit lain; (2) rencana pembelajarannya tidak disusun sendiri oleh subjek, melainkan diperoleh dari munyawarah guru mata pelajaran (MGMP); (3)juga tidak dapat mengidentifikasi kesalahan maupun kesulitan peserta didik; (4) Pusat informasi pada saat pembelajaran hanyalah subjek, dan suasana kelas didominasi oleh subjek; (5) saat siswa mengalami kesulitan maka subjek langsung membantu siswa untuk membetulkan kesalahan tersebut; (6)sumber belajar guru berasal hanya dari buku paket yang disediakan oleh sekolah. Hal tersebut merupakan ciri-ciri dari guru dengan pengetahuan konten pedagogik level 0 (Karahasan, 2010)

Profil pengetahuan konten pedagogik subjek pada program linier pada setiap pertemuan bergantung pada buku paket yang disediakan oleh sekolah. Urutan topik yang disampaikan ke peserta didik sesuai dengan buku paket, meskipun topik tersebut telah diberikan pada saat kelas X. Hal tersebut sesuai dengan yang disampaikan oleh (Mehrpour \& Moghaddam, 2018) bahwa guru pemula saat mengajar mengikuti buku teks urut langkah demi langkah tanpa ada perubahan desain ataupun urutan. Subjek menjelaskan tentang menentukan nilai optimum menggunakan garis selidik. Hal tersebut seperti yang disampaikan oleh (Anwar, Rustaman, Widodo, \& Redjeki, 2014) bahwa guru pemula lebih fokus pada kedalaman materi. (Abd-El-Khalick, 2006) juga menyatakan bahwa lebih rinci dalam menjabarkan materi.

Profil pengetahuan konten pedagogik subjek pada program linier dalam menangani peserta didik yang mengalami kesulitan dengan memberikan jawaban langsung pada peserta didik. hal tersebut sesuai yang disampaikan oleh (Ma'Rufi, Budayasa, \& Juniati, 2018) guru pemula mengatasi kesalahan peserta didik dengan menjelaskan kembali konsep ataupun prosedur pemecahan masalah. Hal tersebut juga sejalan dengan (Moore \& Hu, 2006) bahwa salah satu metode remedial adalah dengan menjelaskan. 


\section{SIMPULAN}

Pengalaman mengajar adalah faktor penting dalam pengetahuan konten pedagogik guru matematika. Profil pengetahuan konten pedagogik guru matematika pemula level 0, pembelajaran mengikuti urutan dalam buku teks. Subjek lebih fokus pada kedalaman materi, juga menjabarkan materi dengan rinci. Saat peserta didik mengalami kesulitan, subjek menjelaskan kembali bagian yang tidak dimengerti dan memberikan jawaban langsung pada peserta didik.

(1) pengetahuan konten pedagogik pada penelitian ini hanya untuk guru matematika SMA sehingga perlu penelitian berikutnya untuk jenjang lain; (2) pengetahuan konten pedagogik pada penelitian ini hanya untuk materi program linier. Oleh karena itu, diharapkan penelitian selanjutnya menggunakan pokok bahasan yang lain sehingga dapat memperkaya pengetahuan konten pedagogik guru matematika; (3) penelitian ini hanya berfokus pada level pengetahuan konten pedagogik guru matematika. Tidak melihat pengarunya level pengetahuan konten pedagogik guru terhadap hasil belajar peserta didik. Oleh karena itu, untuk penelitian berikutnya dapat diteliti apa pengaruh level pengetahuan konten pedagogik guru terhadap hasil belajar peserta didik.

\section{DAFTAR RUJUKAN}

Abd-El-Khalick, F. (2006). Over and Over and Over Again: College Students' Views of Nature of Science. In Scientific Inquiry and Nature of Science (Pp. 389-425). Springer.

Agustiani, R. (2015). Profil Pengetahuan Pedagogik-Konten Mahasiswa Calon Guru Matematika Dalam Melaksanakan Pembelajaran dengan Pendekatan PMRI. Jurnal Pendidikan Matematika JPM RAFA, 1(2), 288-305.

Anwar, Y., Rustaman, N. Y., Widodo, A., \& Redjeki, S. (2014). Kemampuan Pedagogical Content Knowledge Guru Biologi yang Berpengalaman dan yang Belum Berpengalaman. Jurnal Pengajaran Matematika dan Ilmu Pengetahuan Alam, 19(1), 69. https://doi.org/10.18269/jpmipa.V19i1.426

Aunurrahman. (2010). Belajar dan Pembelajaran. Bandung: Alfabeta.

Baumert, J., Kunter, M., Blum, W., Brunner, M., Voss, T., Jordan, A., Tsai, Y.-M. (2010). Teachers' Mathematical Knowledge, Cognitive Activation in The Classroom, and Student Progress. American Educational Research Journal, 47(1), 133-180. https://doi.org/10.1016/0920-5861(95)00084-S

Darling-Hammond, L. (2006). Constructing 21st-Century Teacher Education. Journal of Teacher Education, 57(3), 300-314.

Holt-Reynolds, D. (1992). Personal History-Based Beliefs as Relevant Prior Knowledge In Course Work. American Educational Research Journal, 29(2), 325-349.

Kagan, D. M. (1992). Professional Growth Among Preservice and Beginning Teachers. Review of Educational Research, 62(2), 129-169.

Karahasan, B. (2010). Preservice Secondary Mathematics Teachers' Pedagogical Content Knowledge of Composite and Inverse Fungtion. Middle East Technical University.

Koehler, M. J., \& Mishra, P. (2008). Introducing TPCK (AACTE Comm). Mah-Wah, NJ: Lawrence Erlbaum Associates.

Ma'Rufi., Budayasa, I. K., \& Juniati, D. (2018). Pedagogical Content Knowledge: Teacher's Knowledge of Students in Learning Mathematics on Limit of Function Subject. Journal of Physics: Conference Series, 954(1). https://doi.org/10.1088/1742-6596/954/1/012002

Mastuti, A. G. (2014). Pedagogical Content Knowledge Guru Dalam Pengambilan Keputusan tentang Penugasan Matematis. Disertasi tidak diterbitkan. Universitas Negri Malang, Malang.

Mehrpour, S., \& Moghaddam, M. (2018). Exploring Novice and Experienced Iranian EFL Teachers' Beliefs Representations: A More Vivid Picture. Online Submission, 12(2), 17-50.

Moore, P., \& Hu, B. (2006). A Context Framework for Entity Identification for The Personalisation of Learning in Pedagogic Systems. 2006 10th International Conference On Computer Supported Cooperative Work In Design, 1-6. IEEE.

Purwianingsih, M. W., Rustaman, N. Y., \& Redjeki, M. S. (2010). Pengetahuan Konten Pedagogi dan Urgensinya dalam Pendidikan Guru. Jurnal Pengajaran MIPA, 15(2), 87-94. 